\title{
Effektiwiteit en produktiwiteit in die Christen se lewe, werk en besigheid in die lig van Matteus 25:14-30
}

\author{
J.L. van der Walt
}

Fakulteit Opvoedkunde

Potchefstroomse Universiteit vir $\mathrm{CHO}$

POTCHEFSTROOM

E-pos: jlvdwalt@intekom.co.za

Fika J. van Rensburg

Skool vir Bybelwetenskappe en Bybeltale

Potchefstroomse Universiteit vir $\mathrm{CHO}$

POTCHEFSTROOM

E-pos: sbbjjjvr@puknet.puk.ac.za

\begin{abstract}
Effectiveness and productivity in the Christian's life, work and business in the light of Matthew 25:14-30

In the life of a modern Western Christian, effectiveness and productivity are frequently approached in terms of performativity, operativity and managerialism, which are the characteristic norms of high modernity. Notably New Agers and Postmodernists have questioned such norms in various circles. Should Christians align themselves with the norms of high modernity or with the norms of, for example, Postmodernists in their approach to effectiveness and productivity in their lives, their occupations and their business?

This article offers an interpretation in looking for guidelines regarding a sound approach to this issue. For this purpose the parable of the rich man who entrusted his slaves with his possessions (Matthew 25 (and the parallel Luke 19) is utilised in order to indicate a sound approach to effectiveness and productivity.
\end{abstract}




\section{Inleiding en oriëntering}

In die hedendaagse hoogs moderne samelewing is die vraagstuk van effektiwiteit en produktiwiteit, en veral pogings om dit te verbeter, hoog op die agenda. Elke ministerie, nasionaal of provinsiaal, elke sakeonderneming, elke ambagsman, elke professionele persoon, elke kontrakteur, kortom: elke werkgewer en werknemer kry in die hedendaagse hoogs mededingende samelewing met die eis van (verhoogde) effektiwiteit en produktiwiteit te doen (vgl. die Tirisanoprojek van die Suid-Afrikaanse Onderwysdepartement [Asmal, 1999]).

- Effektiwiteit of doelmatigheid dui op die mate waarin die regte dinge deur die betrokke instansie en sy werknemers gedoen word.

- Doeltreffendheid (efficiency) dui weer op die mate waarin hierdie regte (korrekte, gepaste) dinge op die regte of die beste manier gedoen word.

- Produktiwiteit dui op die mate waarin dié regte produkte of resultate gelewer word ooreenkomstig die visie en die missie van die onderneming of werker, of die mate waarin die middele, hulpbronne of grondstowwe wat benut is, tot die gewenste produksie (in terme van gehalte en omvang) gelei het.

In die hoogs moderne lewe van vandag word effektiwiteit, doeltreffendheid en produktiwiteit meestal vanuit die normstelsel van die hoë moderniteit benader (Blake et al., 1998:1, 5). Die drie vernaamste van hierdie norme of kriteria is performatiwiteit, operatiwiteit (Lyotard, 1984: xxiv) en managerialisme (Blake et al., 1998). Performatiwiteit behels die eis dat effektiwiteit en produktiwiteit in prestasieterme omskryf en benader sal word. Operatiwiteit as kriterium kom neer op die eis dat sodanige prestasie (performance, achievement) in meetbare of minstens aantoonbare terme omskryf en benader moet word. Die sogenaamde managerialisme van die hoë moderniteit wat in die hedendaagse lewe so opvallend geraak het, is die eis of neiging dat effektiwiteit, produktiwiteit en alle aktiwiteite wat daarmee geassosieer word, in die bestuurstaal van die bedryf of sakeonderneming beskryf en benader moet word. So kan 'n mens vind dat die opvoedings- en onderwystaal van die skool, of die wetenskapstaal van die universiteit, of die versorgingstaal van 'n liefdadigheidsorganisasie verdring word deur die diskoers van managerialisme. Daar word byvoorbeeld selfs in hierdie samelewingsorganisasies van "winsmarges", en "inkomste-uitgawebestuur" gepraat terwyl die primêre missie van die betrokke organisasie dikwels uit die oog verloor word. 
Op sigself kan die kriteria van performatiwiteit, operatiwiteit en managerialisme natuurlik nie sonder meer die deur gewys word nie. Daar is uiteraard 'n plek vir hulle, maar die vraag bly of hulle werklik toepaslik is in alle verbandstrukture, veral in ondernemings en organisasies wat klaarblyklik nie primêr bedryfsondernemings is nie (Geertsema, 1992:2123). Die probleem met hierdie kriteria van die hoë moderniteit is dat hulle daartoe neig om van die mens ' $n$ rat, ' $n$ blote werker, in die groot masjien van die organisasie te maak, en om sodoende die waardigheid van die mens as beeld van God aan te tas. Dit is des te meer opvallend in organisasies wat nie primêr as bedryfsondernemings beskou kan word nie (soos skole, universiteite, liefdadigheidsorganisasies).

Die geweldige vooruitgang wat op die terreine van die wetenskap en die tegnologie gemaak is en word, neig om hierdie potensiële degradasie van die mens toenemend 'n werklikheid te maak (vgl. Schuurman, 1977, 1984, 1987, 1995; vgl. ook Van Riessen reeds in 1952). Knellende ekonomiese toestande verhoog die gevaar daarvan verder. Die gevoel ontstaan by mense dat hulle, wat per slot van rekening God se mandaathouers in die skepping is, beheer verloor het (met uitsondering van 'n klein klompie maghebbers, wat bo-aan die sisteem sit, en vir eie gewin die sisteem sowel as diegene met minder mag beheers en manipuleer). Kole (1992:12-13) gee 'n treffende beskrywing van die tweeslagtige mentaliteit van die hoë moderniteit:

Aan die een kant die maghebbers:

De beheersing van de materie d.m.v. electronica, kern-ernergie, computer, medische techniek en opdringende genen-manipulatie, heeft een levensgevoel gekweekt dat het ware geluk en de vrede in het hier-en-nu door de mens zelf te realiseren zouden zijn. ... Deze houding word versterkt door het egoïstische denken: ik, ikke ...

Aan die ander kant die lydende partye:

... de nucleaire dreiging, de steeds groter wordende tegenstelling tussen rijk en arm, tussen Noord en Zuid, en de vervuiling van bodem, water en lucht met afvalstoffen en energieresten die er van nature vaak niet in voorkomen, het uitputten van natuurlijke hulpbronnen en het aantasten op grote schaal van b.v. het tropisch regenwoud ... roepen op om ons te bezinnen op onze verantwoordelijkheid. Het is toch Gods schepping (gebleven) ondanks dat wij meenden en menen dat wij het zonder God wel (zouden) redden.

Met hierdie woorde beskryf Kole die magteloosheid van die gewone mens en van die uitgebuite skepping teen die oormag van die wetenskap 
en die tegnologie en die hoë moderniteitseise van performatiwiteit en operatiwiteit wat daarmee gepaard gaan.

In sommige kringe het daar sterk reaksies gekom teen die uitwasse van die ekstreme verligtingsdenke met sy groot nadruk op die mag en die resultate van die wetenskap en die tegnologie, sowel as sy kriteria van performatiwiteit, ensovoorts. Lyotard (1984:xxiv) het die performatiwiteits- en operatiwiteitsnorme van die hoë moderniteit byvoorbeeld soos volg getipeer - en daarmee ontmasker:

... the decision-makers ... attempt to manage ... sociality according to input-output matrices, following a logic which implies that their elements are commensurable and that the whole is determinable. They allocate our lives for the growth of power ..., the legitimation of that power is based on its optimizing the system's performance efficiency. ... be operational (that is commensurable), or disappear. The logic of maximum performance is no doubt consistent in many ways, particularly with respect to contradiction in the socio-economic field: it demands both less work (to lower production costs) and more (to lessen the social burden of the idle population).... The operativity criterion is technological: it has no relevance for judging what is true or just.

Soortgelyke reaksies word ook deur die postmoderniste verwoord (vgl. Hargreaves, 1994; Ozmon \& Craver, 1995; Usher \& Edwards, 1994). In hulle pogings om die waardigheid van die mens (ook as enkeling) in die moderne tyd onder die aandag te bring en sover as moontlik in ere te herstel, gaan hulle egter soms ander uiterstes op, soos individualisme, relativisme en oordrewe nadruk op dissensus. Die norm vir wat byvoorbeeld as effektief en produktief beskou kan word, word deur elke individu self bepaal, elkeen se eie "verhaal" in die eie kontingente omstandighede is deurslaggewend, en die waarheid word beskou as slegs betreklik, relatief tot die besondere situasie.

\section{Probleemstelling en ondersoekmetode}

Uit die oorsig hierbo is dit duidelik dat die hedendaagse mens hom- of haarself uitgelewer voel aan die uitwerking van óf die hoë moderniteit óf van reaksieverskynsels daarop - soos die postmodernisme, die New Age-beweging, die Neo-Marxisme en ander meer gematigde subversiewe benaderings soos dié waarvan Hans A. Pestalozzi (1979) reeds meer as 20 jaar lank 'n eksponent is. Soos blyk uit die werke van Schuurman, Van Riessen en Geertsema waarna hierbo verwys is, is daar ook onder Christendenkers besorgdheid en kommer oor die gevolge en uitwerking van die hedendaagse hoë moderniteit met sy oordrewe rasionalistiese 
onder- en botone, asook oor die probleme wat meegebring word deur reaksieverskynsels daarop.

Die vraag waarop ' $n$ antwoord gesoek moet word is of die Bybel, die Skrifwoord van God, enige prinsipiële riglyne verskaf aan die hedendaagse bedryfsleier, werker, akademikus, professionele persoon, vakman, kontrakteur - kortom: aan elke Christen - oor hoe die vraagstuk van effektiwiteit en produktiwiteit in die Christen se lewe, werk en besigheid (dit is: alles waarmee die mens besig is) benader behoort te word.

In die soeke na 'n antwoord op hierdie vraag word 'n aantal ondersoekstappe uitgevoer. Ten eerste word Skrifgedeeltes wat op die een of ander manier met die vraagstuk van effektiwiteit en produktiwiteit in verband gebring kan word, geïdentifiseer. 'n Kursoriese eksegese is op hulle uitgevoer, en op die grondslag daarvan is Matteus 25:14-30 (en sy parallel in Lukas 19:17-24) vir nadere ondersoek uitgesonder. Hierdie twee Skrifgedeeltes is besonder ryk aan riglyne vir die hantering van die onderhawige probleem. Vervolgens word 'n meer diepgaande grammaties-historiese eksegese (Roberts \& Du Toit, 1977:68) van hierdie twee perikope gedoen. Die sosio-historiese metode ${ }^{1}$ soos toegepas deur Malherbe (1983), Stambaugh en Balch (1986) en getipeer deur Garrett (1992:89-99), word gebruik, maar dan vanuit 'n bepaalde teologiese perspektief, naamlik die Gereformeerde Skrifbeskouing 2 (Jordaan, 1991: 14; Van Rensburg, 1992:13), en vanuit 'n bepaalde teksbeskouing ${ }^{3}$ (Van Rensburg, 1992:14). Ten slotte word tot sekere gevolgtrekkings gekom wat kan dien as 'n riglyn vir die Skrifgelowige se benadering tot effektiwiteit en produktiwiteit in die verskillende lewensverbande waarin die hedendaagse mens leef en werk.

1 Die sosio-historiese metode word onderskei van die sosio-wetenskaplike metode soos toegepas deur onder andere Elliott (1990) en Botha (1991:255-272). Die eksegese is dus sosiaal gerig, en nie sosiologies nie. Waar van toepassing, word wel van die navorsingsresultate van die sosio-wetenskaplike metode gebruik gemaak.

2 Die teologiese perspektief van waaruit hierdie artikel geskryf is, is die volgende: Matteus (en Lukas) maak deel uit van die kanon van die Nuwe Testament en is daarom gesagvol vir die gelowige. In onderskeiding van Elliott (1990:21) word die mening gehuldig dat die boeke van die Nuwe Testament veel meer is as net die produk van of 'n bydrae tot 'n wordende sosiale wêreld. Hierdie boeke is net soos die OuTestamentiese boeke organies deur God geïnspireer. Dit word nie as tydgebonde beskou nie, maar as tydgerig met implikasies vir Christene vandag (Coetzee et al., 1980:17).

3 As uitgangspunt word geneem dat die teks self betekenis het en dat dit die verantwoordelikheid van die interpreteerder is om deur middel van geldige wetenskaplike metodes en met die uitspel van sy of haar voorveronderstellings, daarna te streef om die boodskap van die teks al akkurater te formuleer (Van Rensburg, 1992:14). 


\section{Die Skrif oor effektiwiteit en produktiwiteit}

Daar is nogal heelwat kultuur-historiese beskrywings sowel as normatiewe uitsprake in die Skrif wat regstreeks of onregstreeks met die vraagstuk van effektiwiteit en produktiwiteit te doen het. Omdat die scopus van die Skrif egter gerig is op die verhouding tussen God en die mens ten opsigte van die skepping, die afvallige skepping en die herskepping in Christus, is daar nie pertinente verwysings na effektiwiteit en produktiwiteit oor byvoorbeeld sakebedrywe in die Skrif nie. Selfs verwysings wat op die oog af met geld, sake, bedryf, vervaardiging of boerdery te make het, fokus in laaste instansie op hierdie innige persoonlike verhouding tussen God en die mens as beeld en mandaathouer van God. So, byvoorbeeld, spoor 2 Korintiërs 5:9 die gelowige aan om volgens God se wil te lewe, en in Filippense 3:12-14 stel Paulus dat hy strewe na die hemelse prys in Jesus Christus. 1 Tessalonisense 4:11 toon die belangrikheid van 'n rustige en finansieel-onafhanklike lewe, terwyl 1 Timoteus 6:11 wys op die noodsaaklikheid van toewyding aan God. Soeke na aardse rykdom as uiteindelike strewe van die mens word in verskillende Skrifdele afgewys - onder andere in 1 Konings 3:11, Lukas 12:13-21 en 1 Timoteus 6:9-10.

Die Skrif raak egter ook wel temas aan wat op die een of ander manier verband hou met die vraagstuk van effektiwiteit en produktiwiteit in die lewe van 'n Christen. 'n Mens dink hier aan verwysings na diens, bediening en bediendes, die baas-slaaf-verhouding, die vraagstukke rondom hebsug en mag, asook vraagstukke oor beloning, dissipelskap, integriteit, die juk wat elkeen in die diens van God moet dra, roeping en priesterskap, skuld, slawerny, vreugde en die roeping deur God om in sy wingerd te werk. Temas oor werk/arbeid en rentmeesterskap is ook hierby ter sake.

Matteus 25:14-30 (en sy parallel in Lukas 19:17-24) word in hierdie artikel uitgesonder vir meer diepgaande ondersoek omdat hierdie gelykenis (twee gelykenisse?) volgens die twee evangelie-outeurs uit die mond van Jesus self kom in die konteks van sy onderrig aan die gelowiges om wakker en gereed te wees met die oog op die aanbreek van die eindtyd (Cammeraat, 1999:251). Verder hou dit duidelik verband met die vraagstukke van geld, produksie, sake, produktiwiteit, rentmeesterskap en getrouheid in die afwesigheid van die "baas".

Daar is aanduidings dat hierdie gelykenis (twee gelykenisse?) sekere aanpassings ondergaan het in die proses van oorvertelling, en dat kantaantekeninge gemaak kon gewees het wat later deel van die teks geword het (vgl. ook die kontroversiële uitsprake van Funk \& Hoover, 1993:256 e.v.). Desondanks bied hierdie gelykenis (en sy parallel) 'n 
gedagtelyn en verloop waaruit sekere afleidings en gevolgtrekkings oor die onderhawige vraagstuk gemaak kan word.

\section{Een of twee gelykenisse}

Dit is nie ' $n$ uitgemaakte saak dat die gelykenis wat in Matteus 25 verskyn en die een wat in Lukas 19 verhaal word, twee weergawes van een en dieselfde gelykenis uit die mond van Jesus Christus is nie. Hulle verskil op sommige plekke selfs substansieel van mekaar, tot so 'n mate so dat Van Bruggen (1990:430) meen dat die eksegese van Matteus 25:14-30 gedoen kan word sonder dat dit beïnvloed hoef te word deur Lukas 19:11-28. Die ooreenkomste is egter opvallend. Vir die doel van hierdie artikel is dit egter nie van deurslaggewende belang of hierdie twee gelykenisse is, of twee weergawes van een en dieselfde gelykenis nie. As hulle langs mekaar gestel word, is die ooreenkomste en verskille opvallend, en kan sekere gevolgtrekkings uit albei saam gemaak word.

\begin{tabular}{ll|l}
\multicolumn{1}{c|}{ Matteus 25 } & \multicolumn{1}{c}{ Lukas 19 } \\
\hline 14. $\begin{array}{l}\text { Verder gaan dit soos met 'n man } \\
\text { wat op reis wou gaan. }\end{array}$ & \begin{tabular}{l} 
12. $\begin{array}{l}\text { 'n man van adellike afkoms } \\
\text { het na 'n ver land op reis gegaan } \\
\ldots\end{array}$ \\
\hline $\begin{array}{l}\text { Hy het sy slawe bymekaar ge- } \\
\text { roep en sy besittings aan hulle } \\
\text { toevertrou. }\end{array}$
\end{tabular} & $\begin{array}{l}\text { Vooraf het hy tien van sy slawe } \\
\text { geroep en aan hulle tien goue } \\
\text { muntstukke gegee en gesê: } \\
\text { "Dryf handel daarmee tot ek te- } \\
\text { rugkom." }\end{array}$ \\
\hline 15. & $\begin{array}{l}\text { Vir die een het hy vyf goue munt- } \\
\text { stukke gegee, vir 'n ander twee, } \\
\text { en vir die derde een. }\end{array}$ & \\
\hline $\begin{array}{l}\text { Hy het aan elkeen volgens sy } \\
\text { bekwaamheid gegee en toe op } \\
\text { reis gegaan. }\end{array}$ & \\
\hline $16 . \quad \begin{array}{l}\text { Die een wat vyf goue munt- } \\
\text { stukke ontvang het, het dadelik } \\
\text { daarmee gaan werk en 'n wins } \\
\text { gemaak van nog vyf. }\end{array}$ & \\
\hline 17. & $\begin{array}{l}\text { So ook die een wat twee gekry } \\
\text { het: hy het 'n wins gemaak van } \\
\text { nog twee. }\end{array}$ \\
\hline
\end{tabular}


18. Maar die slaaf wat een gekry het, het 'n gat in die grond gaan grawe en sy eienaar se geld daarin weggesteek.

19. $\mathrm{Na}$ 'n lang tyd het die eienaar van daardie slawe teruggekom en van hulle rekenskap gevra.

15. Nadat hy teruggekom het, het hy die slawe aan wie hy die geld gegee het, na hom laat roep, sodat hy kon verneem wat hulle met die handeldryf verdien het,

20. Die een wat die vyf goue munt-

16. Die eerste het vorentoe gekom stukke ontvang het, kom toe en sê: "Meneer, vyf goue muntstukke het $u$ aan my toevertrou. Hier is dit met vyf ander wat ek wins gemaak het."

21. Toe sê die eienaar vir hom: "Mooi so! Jy is 'n goeie en getroue slaaf. Oor min was jy getrou, oor baie sal ek jou aanstel. Kom in en deel in my vreugde."

22. Toe kom die een met die twee goue muntstukke en sê: "Meneer, twee goue muntstukke het $u$ aan my toevertrou. Hier is dit met twee ander wat ek wins gemaak het."

17. Daarop antwoord hy: "Mooi so, jy is 'n getroue slaaf. Omdat jy in 'n saak van min belang getrou was, kry jy nou die bestuur oor tien stede."

18. Toe kom die tweede slaaf en sê: "Meneer, u muntstuk het vyf muntstukke opgelewer."

19. Aan hierdie een sê hy: "En jy kry die bestuur oor vyf stede." so! Jy is 'n goeie en getroue slaaf. Oor min was jy getrou, oor baie sal ek jou aanstel. Kom in en deel in my vreugde." (...)

24. Toe kom die een wat een goue muntstuk ontvang het, en sê: "Meneer, ek ken u en weet dat u 'n harde man is, wat oes waar $u$ nie gesaai het nie, en pluk waar $u$ nie geplant het nie.

20. Nog 'n ander het gekom en gesê: "Meneer, hier is $u$ muntstuk. Ek het dit in 'n doek gebêre.

Omdat ek bang was, het ek $u$ muntstuk in die grond gaan be-

21. Ek was bang vir $u$, want $u$ is ' $n$ grawe. Hier het u u geld terug." harde man. $U$ eis wat $u$ nie belê het nie, en oes wat u nie gesaai het nie." 
26. Toe sê die eienaar vir hom: "Jy is 'n slegte en lui slaaf! Jy het geweet dat ek oes waar ek nie gesaai het nie en pluk waar ek nie geplant het nie.
22. Toe sê hy vir hom: "Met jou eie woorde sal ek jou veroordeel. Jy is 'n slegte slaaf! As jy geweet het ek is 'n harde man wat opeis wat ek nie belê het nie, en oes wat ek nie gesaai het nie,

27. Dan moes jy my geld in die bank gesit het, en ek sou dit by my koms met rente teruggekry het.

\section{3.}

waarom het jy dan nie my geld in die bank gesit nie? Dan sou ek dit by my terugkoms darem met rente kon getrek het."

28. Vat die muntstuk van hom af

24. Daarop sê hy vir dié wat daar weg en gee dit aan die een wat die tien het." (...) hom af weg en gee dit vir die een wat tien muntstukke het." (...)

\section{Bespreking}

Hoewel Van Bruggen (1990:430) van mening is dat die eksegese van Matteus 25:14-30 behoort gedoen te word sonder "beïnvloeding" van Lukas 19:11-28, is dit nie onredelik om te aanvaar dat hierdie twee weergawes van een en dieselfde gelykenis is, en dat hulle mekaar op verskillende plekke kan aanvul nie. Die twee weergawes van die gelykenis verskil wel in sekere detailopsigte van mekaar, soos hierbo aangetoon is, en daar is allerlei "oneffenhede" (die getal muntstukke verskil byvoorbeeld, en daar word soms van stede gepraat en dan weer van muntstukke). Die kern van die gelykenis is egter heeltemal duidelik, en dit is ook duidelik dat die strekking daarvan volledig ad rem is vir 'n soeke na Skriftuurlike riglyne vir die vraagstuk van effektiwiteit (die doen van die regte dinge en wel op die regte manier) en produktiwiteit (die optimale lewering van produkte met die beskikbare middele en bronne).

Skrifverklaarders wys die allegoriese trekke van hierdie gelykenis uit (die vermoënde $\operatorname{man}=$ Christus; reis $=$ hemelvaart; ver land $=$ hemel; slawe $=$ gelowiges, kerk of apostels; terugkeer = terugkeer van Christus; rekenskap = finale afrekening, ensovoorts) (Ridderbos, 1954; Barclay, 1975; Interpreter's Bible, 1954; Cammeraat, 1999). Daar is selfs sommige Skrifverklaarders wat die gelykenis as sterk allegories verklaar (vgl. Van Bruggen, 1990; Henry, 1993). Hierdie artikel wil nie in die eerste plek hieroor uitsluitsel kry nie; die doel is eerder om vas te stel of die gelykenis enige riglyne bied vir 'n ewewigtige benadering tot effektiwiteit en produktiwiteit in die Christen se lewe, werk en besigheid. 


\section{- Die sosio-historiese konteks van die gelykenis}

Jesus verduidelik met die gelykenis aan sy hoorders iets van God se verhouding met die mens. Hy doen dit met die destyds gangbare verhouding tussen 'n eienaar en sy slawe. Hy sê dat daar 'n tyd gaan kom wanneer die gelowige - in terme van die gelykenis - voor God gaan staan, en een van twee uitsprake uit sy mond gaan hoor:

- Mooi so! Jy is 'n goeie en getroue slaaf! Kom in en deel in my vreugde! (Matt. 25:21.23);

- Jy is 'n slegte en 'n lui slaaf! Gooi dié slaaf uit in die diepste duisternis daarbuite! (Matt. 25:26, 30).

Die slawepraktyk is nie meer vandag bekend nie. Die volle impak van die gelykenis was waarskynlik onmiddellik vir Jesus se eerste hoorders duidelik, want hulle het die verhouding tussen slawe en eienaars geken. Trouens, baie van hulle wás self eienaars van slawe, en ander was waarskynlik weer sélf slawe.

Sodat die volle impak van hierdie gelykenis duidelik kan word, moet ten minste twee sake oor die aard en posisie van slawe destyds uitgelig word: 4

- Slawe was nie net ongeskoolde handearbeiders nie. Na oorloë het die oorwinnende volk die beste slawe gevat (dink byvoorbeeld aan Daniël in die Ou Testament). Aan bekwame en goed gekwalifiseerde slawe is hoë posisies met groot verantwoordelikhede gegee. Soos in hierdie gelykenis waar - in terme van die huidige Suid-Afrikaanse geldwaarde - miljoene rande se projekte aan die slawe opgedra word.

- 'n Slaaf het nie 'n "beloning", 'n salaris gekry nie. Hy het behoort aan sy eienaar, en watter opbrengs hy ook al bewerkstellig het, was maar sy eienaar s'n; soos een van die eienaar se ooie se lammetjie die eienaar se eiendom was en gebly het.

Hierdie verskynsel dat 'n slaaf geen beloning kry nie, word ook besonder duidelik as mens 'n ander uitspraak van Jesus in gedagte hou:

Sê nou een van julle het 'n slaaf wat ploeg of vee oppas. Sal hy vir die slaaf sê as hy van die veld af inkom: 'Kom eet eers gou'? Natuurlik nie! Maar hy sal vir hom sê: 'Maak vir my iets klaar vir

$4 \quad$ Vergelyk Bartchy (1992), Hopkins (1978), Macmullen (1974) en Van Wyk \& Van Rensburg (1997) vir omvattende oorsigte oor die posisie van slawe in die eerste-eeuse Grieks-Romeinse samelewing, en die implikasie daarvan vir die verstaan van tersaaklike Skrifdele. 
aandete. Sit dan jou voorskoot aan en kom bedien my terwyl ek eet en drink'. 'n Slaaf wat sy opdrag uitgevoer het, word mos nie bedank nie, of hoe? So is dit ook met julle: as julle alles gedoen het wat aan julle opgedra is, sê dan: Ons is slawe wat niks verdien nie. Ons het gedoen wat ons verplig was om te doen (Luk. 17:7-10).

Dit verduidelik hoe die gelowige voor die Here oor pligvervulling moet voel: As jy alles gedoen het wat jy moet, het jy nog niks verdien nie; jy het net jou plig gedoen!

Dit word egter uit die Skrif duidelik dat Christus self juis hierdie samelewingsgebruik van sy tyd op sy kop kom draai. In Johannes 13 vertel die evangelieskrywer hoedat Hy saam met die twaalf aan tafel is. Een van hulle moet die slawewerk doen om volgens die gebruik van destyds almal se voete te was nadat hulle by die tafel aangelê het. Maar wat doen Jesus?

Toe het Jesus van die tafel af opgestaan, sy bokleed uitgetrek en 'n handdoek gevat en om Hom vasgemaak. Daarna het Hy water in 'n wasskottel gegooi en begin om sy dissipels se voete te was en dit dan af te droog met die handdoek wat Hy omgehad het (Joh. 13:4$5)$.

Hy wat met reg volgens sy eie waarneming in Lukas 17 die opdrag vir sy dissipels kon gegee het: "Was my voete!" -

- Hy word slaaf vir dié wat eintlik sý slawe is;

- Hy behandel hulle asof hulle die eienaar is.

Nou word die besonderse van die gelykenis wat Jesus in Matteus 25:1430 vertel het, duidelik. Hy, die eintlike, die almagtige Eienaar, die Besitter en Skepper van die heelal praat met elke gelowige: "Mooi so! Jy is 'n goeie en getroue slaaf. Kom in en deel in my vreugde!"

In die lig van hierdie perspektiewe op grond van die slaafbeeld wat Jesus gebruik, kan die ander hoofmomente van die gelykenis nou aan die orde kom:

\section{- 'n Vermoënde man gaan op reis}

Om die een of ander rede moet 'n vermoënde man op 'n reis gaan na 'n ver land (Lukas 19 se man gaan op reis om 'n koningskap te gaan opneem [19:12].). Hy roep sy slawe byeen, en vertrou sy besittings aan hulle toe. Hy laat dit in hulle sorg om op verantwoordelike wyse daarmee om te gaan. In die gelykenis in Matteus gee hy nie 'n duidelike opdrag in verband met sy besittings nie, maar in Lukas gee hy aan hulle die opdrag om daarmee handel te dryf (19:13). Die vermoënde man vertrek 
en bly baie lank weg, wat aan die slawe genoeg geleentheid gee om met die besittings te woeker en wins te maak. Dit val op dat die vermoënde man baie besittings aan slawe toevertrou (Cammeraat, 1999:251), en dat hy vertrou dat hulle nie daarmee sal dros nie.

\section{- Die aard van die besittings}

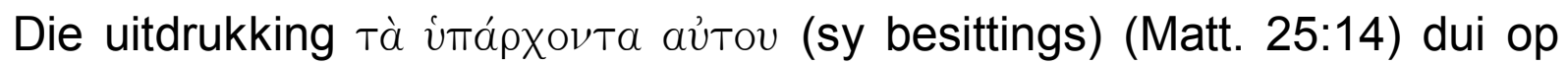
die geheel van sy besittings, alles wat hy gehad het. Hy het met ander woorde sy hele besit net so aan die slawe toevertrou toe hy op die reis moes vertrek. Hy het hulle as 't ware as bestuurders oor sy groot bedryf aangestel, elkeen met 'n spesifieke mandaat, ooreenkomstig die betrokke slaaf se vermoëns en ervaring. Die waarde van die toekenning aan elkeen is aansienlik. Een van die goue muntstukke (die geldeenheid is in Grieks 'n tád $\alpha \nu \tau o v$, waar ons woord talent vandaan kom) was ongeveer 6000 denarii werd, wat 'n dagloner 20 jaar sou neem om te verdien (Hendriksen, 1973:879; Van Zyl, 1999:1175). In vandag se geldwaarde omgereken, het die slaaf met een muntstuk ongeveer R292 000 ontvang, en dié een met vyf byna R1.5 miljoen.

\section{- Die vertroue van die vermoënde man in sy slawe}

Die vermoënde man gee aan elkeen van die slawe kapitaal volgens die vermoë (letterlik: drakrag [Cammeraat, 1999:251]) van die betrokke slaaf. Die vermoënde man het sy slawe dus goed geken. Trouens, hy het hulle waarskynlik op 'n slawevendusie gekoop juis op grond van hulle bewese vermoëns, kwalifikasies en ervaring. Hy het dus geweet dat hy nie aan almal ewe veel kon toevertrou nie. Hy het al drie egter vertrou, dermate dat hy hierdie groot bedrae aan hulle gegee het, en weggegaan het sonder om enige toesig oor hulle te stel.

\section{- Die vermoënde man se verwagtings}

Dit blyk later aan in die gelykenis dat die slegte en lui slaaf die vermoënde man as ' $n$ harde baas beleef het. Hy het hom beleef as iemand wat die gewoonte het om te oes waar hy nie self gesaai het nie, en om te pluk waar hy nie self geplant het nie. Hy was dus 'n eienaar wat stilswyend aanvaar het dat sy werkers hulle take in sy diens sou verstaan en sou uitvoer. Dit was nie eens vir hom nodig om 'n duidelike opdrag te gee by sy vertrek nie. Die slawe het hom goed genoeg geken om te weet dat hy sekere verwagtings het wat by sy terugkeer moes realiseer. Hy het stilswyend verwag dat hulle met sy besittings hulle bes sou doen. 


\section{- Die optrede van die slawe ná sy vertrek}

Tipies soos wat dit in die werklike lewe sou kon gaan, spring twee van die slawe direk na die eienaar se vertrek aan die werk. Matteus 25:16-17 sê dat hulle dadelik met die geld begin werk het en wins gemaak het. Die derde, wat sy eienaar net so goed soos die ander twee geken het, maar vanweë sy eie instelling hom as 'n harde baas beleef het, het egter sy goue muntstuk veilig weggebêre. Hy het konserwatisties die besitting probeer beveilig teen skuldeisers en moontlike diewe. Die ander twee slawe neem egter inisiatief, lê ondernemingsgees asook verantwoordelike waagmoed aan die dag, en hulle maak wins. Die derde slaaf besluit egter om die besitting slegs veilig te bewaar en dit nie eens in 'n bank te plaas waar dit moontlik rente kan verdien nie.

\section{- Rekenskap by die terugkeer van die eienaar}

Die vermoënde man bly lank genoeg weg vir elkeen van hierdie slawe om sy staal te toon. By sy terugkeer eis hy rekenskap van elkeen van hulle oor wat hulle met die toevertroude besittings gemaak het. Die eerste twee rapporteer dat hulle die besitting wat aan hulle toevertrou is, verdubbel het deur hulle pogings. Die derde slaaf gee slegs aan die eienaar terug wat aan laasgenoemde behoort sonder enige toevoeging aan die waarde daarvan.

\section{- Die reaksie van die vermoënde man}

Die twee slawe wat waarde toegevoeg het aan die besittings, word geprys vir hulle optrede en hulle word beloon. Die derde slaaf word gekritiseer en bestempel as lui en sleg, en die muntstuk in sy besit word aan die eerste gegee. As die derde slaaf homself probeer verweer deur op die hardheid en die ongenaakbaarheid van die eienaar te wys, boemerang die verwyt op hom: hy moes geweet het om met die besitting te woeker, aangesien die eienaar 'n harde man is wat hoë eise stel. Bowendien, dit is nie waar dat die vermoënde man probeer oes waar hy nie gesaai het nie. Hy het aan die slaaf genoeg kapitaal gegee waarmee hy kon woeker as hy wou.

\section{- Die eindwaarde van die besittings}

Hoewel, soos hierbo aangetoon is, die besittings aansienlike bedrae geld verteenwoordig het, noem die vermoënde man dit "min" ("heel kleinste dingetjies" [Van der Watt \& Joubert, 1997:272]) in vergelyking met dit waarmee hulle voortaan toevertrou sou word (Matt. 25:21-22; Luk. 19:919). Die slawe was oor min getrou en sal derhalwe oor meer aangestel word. Die wins of die rente wat met die besittings gemaak is (of potensieel gemaak kon gewees het) word dus deur die vermoënde man 
afgemaak as "min", iets nietigs. Hy het op iets anders gelet as op wins en rente.

\section{- Waarop die eienaar gelet het}

Die vermoënde man het nie soseer gelet op die hoeveelheid waarde wat aan sy besittings toegevoeg is nie. (Trouens, volgens die Lukas-weergawe van die verhaal, het hy teruggekom as 'n koning met baie besittings, en kon hy die bestuur van stede aan die eerste twee slawe toevertrou.) Die optrede van die slawe, en die wyse waarop hulle in sy diens hulle taak nagekom het, was vir hom verreweg belangriker.

\section{- Die rekenskap}

Die swaartepunt van hierdie gelykenis lê in die afrekeningsfase, en nie in die toedelingsfase nie. Anders gesê: die uitsetfase is belangriker as die insetfase. Dit is nie so belangrik wat elkeen ontvang het nie; belangriker is wat hulle uitgerig het met dit wat aan hulle toevertrou is.

\section{- Die tersaaklike boodskap van die gelykenis saamgevat}

Die gelykenis gee 'n voorskrif oor die manier waarop die gelowige die lang wag tot die terugkeer van Christus moet deurbring - deur die wil van God uit te leef. Muntstuk slaan op die gawe van die koninkryk van God waarmee gewoeker moet word (Van Zyl, 1999:1175).

Die enorme bedrag wat elke slaaf kry, bly die eienaar se eiendom; hy vertrou dit slegs aan hulle toe (Matt. 25:14) met die bedoeling dat hulle met sy volmag daarmee sal wins maak. En al is dit baie geld, hoef nie een daaroor beangs te voel nie, want elkeen ontvang volgens sy bekwaamheid (25:15). Elkeen beskik oor die nodige aanleg, kundigheid en ervaring om van sy deel 'n sukses te maak.

Die slawe wat onderskeidelik vyf en twee muntstukke gekry het, is deur die eienaar beloon met lof, groter verantwoordelikheid en feesvreugde (Matt. 25:21, 23). Dit onderstreep die aard van die beloning as voluit genade. Hulle was maar net daarin getrou om die eienaar se groot kapitaal aan te wend en te benut. Verder is die nuwe verantwoordelikhede buite verhouding groot tot wat aanvanklik aan hulle toevertrou is. En boonop deel hulle in die fees wat die eienaar voorberei het, iets wat in daardie kultuur totaal ongehoord was (vgl. Lukas 17 soos hierbo aangehaal). Die ete sinspeel op die Messiaanse feesmaal waarvan Jesaja 25:6-8 praat (Van Zyl, 1999:1175).

Hierteenoor gee die slaaf met die een muntstuk dit bloot aan sy eienaar terug (25:25). Nou moet hy egter die eienaar se gramskap verduur, want hy hoor hoe sleg en lui hy is. Wat hy ontvang het, het hy nooit sy eie 
gemaak nie. En dit blyk dat wat jy nie gebruik nie, jy totaal verloor. Maar wat jy aanwend en benut, ontvang jy in oorvloed terug (vgl. Van Zyl, 1999:1175).

Met hierdie gelykenis leer Jesus die gelowiges wat hulle moet doen met die gawe van die koninkryk van die hemel, oftewel: die gawe van God se liefde en barmhartigheid. Dit is 'n oorweldigende groot gawe wat Christus aan God se kinders toevertrou en waarmee hulle moet woeker tot die dag van sy koms in heerlikheid. Deur dit te begrawe, bewys die betrokkene dat dit hom/haar koud laat. Die gelykenis wys egter dat God oor sy eis van liefde en barmhartigheid "onverbiddelik" is (Matt. 25:24). Daaroor gaan Hy geen kompromieë aan nie. Daarom sal sy oordeel so 'n mens se ware self ontmasker: "Jy is 'n slegte en lui slaaf" (25:26); jy't My nie lief nie, net jouself.

Die bedoeling van die gawe van die liefde is dat dit moet wérk. Gelowiges mag maar risiko's daarmee neem (Van Zyl, 1999:1175). Dan tree die wet van die koninkryk in werking: dit groei honderdvoudig, want dis God se liefde wat vrygestel word. Dit neem sy eie loop en word meer en meer. En die uiteinde daarvan is die voorreg om te deel in die ewige vreugde van die Here (vgl. Van Zyl, 1999:1175)

Met hierdie gelykenis herinner die Here elke gelowige vandag dat vreugdesoeke, die terughunker na die vae paradysherinnering - ook in die werksituasie - níe net ' $n$ romantiese gevoel of ' $n$ mite is waarvan die mens liewer moet vergeet om verdere ontnugtering te voorkom nie. Die gelykenis laat die gelowige se geestesoor God hoor sê: Kom in en deel in my vreugde! Elke gelowige hoor dus die Here met hierdie Skrifdeel sê: Kom Ek wys jou hoe jy die diepste vreugde permanent hét; kom Ek wys jou wat dit inhou!

Die Eienaar moes gepraat het soos Lukas 7:7-10 dit impliseer: Jy het jou plig gedoen; kom bedien my nou verder ...! Tog hoor die gelowige die teendeel: Kom in en déél in mý vreugde! En dit nie omdat hy/sy so besonder is nie, maar omdat Jesus Christus vir elke kind van God slaaf geword het, sodat hy/sy nou soos 'n kind in die Vaderhuis verwelkom word.

Hierdie wete het 'n paradigmaskuiwende effek op elke gelowige. Jy woeker met die muntstukke wat God aan jou toevertrou. Jy maak wins daarmee vir jou Eienaar. Nie angsvallig omdat jy wonder of die Eienaar tevrede gaan wees nie, maar met die rustige sekerheid van iemand wat nou al vooruit hoor: Mooi so! Jy is 'n goeie en getroue slaaf! Kom in en deel in my vreugde! Die gelowige kry dus eintlik 'n voorsmaak en ervaar 
iets van God wat hom/haar geniet soos 'n kunstenaar van sy kunsskepping af terugstaan en dit geniet.

Elke gelowige wat besef dat die Here hom/haar inroep om te déél in sý vreugde, se beroepslewe en al sy ander aktiwiteite sal wys dat hy/sy die diepste vreugde hét.

\section{Implikasies vir effektiwiteit en produktiwiteit in die Christen se lewe, werk en besigheid}

Die Skrifgelowige verstaan dat hy/sy op die aarde gestel is met 'n bepaalde opdrag, 'n mandaat om die aarde te bewoon, te bewerk en te bewaak, of - in terme van die gelykenis - om wins te maak met die muntstukke wat God aan hom toevertrou het. Vir hierdie taak het elkeen sekere vermoëns en middele gekry. Die gelowige het ook 'n baie duidelike opvatting van sy/haar roeping in diens van God en die naaste. Hierdie roeping word onder meer uitgeleef in die alledaagse lewe, in werk en in die verskillende bedrywe/bedrywighede waarby gelowiges betrokke is (vgl. Ef. 4:7; 2 Kor. 3:5, Matt. 24:47), en is van die uiterste belang in die perspektief van Jesus se terugkeer.

Die rekenskap-fase van hierdie gelykenis maak dit duidelik dat wanneer Christene verslag moet doen oor die wyse waarop hulle omgegaan het met die besittings, die middele en die bronne wat aan hulle toevertrou is, daar wel ' $n$ vorm van waardetoevoeging moet wees. In algemene terme sou 'n mens kon sê dat die mens uit die natuur, deur middel van die mens se beheersingstaak, allerlei vorme van kultuur behoort te skep. In besondere sin kan 'n mens sê dat 'n mens waarde behoort toe te voeg tot die omgewing waarin jy leef, werk en bedrywig is. Waardetoevoeging is uiters belangrik vir die wyse waarop die Christen met God se skepping omgaan, asook met die middele wat aan ondergeskiktes toevertrou word. Van der Watt en Joubert (1997:104) vertaal die eis van die eienaar in Matteus 25 as "ek is streng en verwag net die beste van julle".

Die gelykenis onderstreep egter tegelyk ook dat 'n gejaag na performatiwiteit en operatiwiteit, dit wil sê na waardetoevoeging slegs in terme van prestasienorme en in terme van meetbaarhede, soos syfers en persentasies, nie deurslaggewend is nie. Selfs groot bedrae word deur die eienaar in die gelykenis as "weinig" bestempel. Daar is ander oorwegings in die proses van waardetoevoeging wat belangriker is, soos die volgende:

- Taakbewustheid: verstaan die werker die taak, en weet hy/sy wat verwag word deur die opdraggewer? 
- Diepe verantwoordelikheidsbesef: is die werker onder die besef van die verantwoordelikheid om waarde toe te voeg aan dit wat aan hom of haar toevertrou is?

- Hulpbronne/middele: beskik die werker oor genoeg hulpbronne en middele om te kan voldoen aan die verwagtings van die eienaar?

- Kennis van die opdraggewer: ken die werker die opdraggewer so goed dat hy/sy weet wat die opdraggewer verwag, selfs sonder uitdruklike opdragte; dat die opdraggewer 'n regverdige baas is, en rekenskap sal kom eis?

- Vermoëns: kan die werker die opdraggewer tevrede stel nadat laasgenoemde die werker vertrou het met 'n taak wat na sy (die opdraggewer se) oordeel pas by die vermoëns van die werker? Sal die werker sy/haar vermoëns optimaal (kan) gebruik?

- Roepingsbesef: wil die werker die taak waartoe die opdraggewer hom/haar, selfs stilswyend, geroep het, uitvoer?

- Ywer: kan die opdraggewer aanvaar dat die werker ywerig sal werk met die "besittings"?

- Ondernemingsgees / inisiatief / waagmoed: kan die opdraggewer aanvaar dat die werker uit eie beweging sekere stappe sal neem om die waarde van die "besittings" te vermeerder (al misluk die stappe soms)? (Een verklaarder is van mening dat die werker avontuurlustig moet wees, 'n oop gemoed moet hê om die moontlikhede raak te sien [Barclay, 1975]).

- Rentmeesterskap: besef die werker dat hy/sy die verteenwoordiger van die eienaar is wanneer die eienaar weg is, en met die eienaar se "besittings" behoort om te gaan asof dit sy/haar eie is?

- Gereed wees vir die terugkeer: werk die werker op so 'n wyse dat rekenskap te enige oomblik wanneer die eienaar sou terugkeer, gegee kan word?

- Betroubaarheid: is die werker só betroubaar dat die eienaar sy besittings in sy/haar sorg kan plaas, en vir 'n onbepaalde tyd kan weggaan? (Volgens Cammeraat [1999:253] val die meeste nadruk in hierdie gelykenis juis op getrouheid.)

- Bedagtheid op die voordeel van die eienaar: is die werker bedag op elke geleentheid waarmee hy/sy voordeel vir die eienaar kan verseker? (Zahn, 1910).

- Rekenskap: is die werker in staat om die verwagte vorm van rekenskap te gee? (In die gelykenis bestaan die rekenskap uit twee fases: bewaring van die eienaar se besitting, en toevoeging van waarde 
daartoe. Twee van die slawe kon rekenskap gee oor die uitvoering van albei fases; die lui, slegte slaaf slegs oor die eerste fase. Sy handelswyse was goed, maar nie produktief nie [Van Bruggen, 1990]).

- (Arbeids)vreugde: besef die werker dat hy/sy nie angsvallig 'n prestasiedrang hoef te hê nie, maar rustig kan woeker met die toevertroude "besittings"? Die eienaar het hulle immers van blote slawe tot sy eie kinders omvorm, en hulle gaan vir seker deel wees van God se vreugde.

\section{Gevolgtrekking: enkele bestuursriglyne}

Die ontleding van Matteus 25:14-30 (met verrekening van Lukas 19:1724) bring aan die lig dat Christene nie in hulle lewens, werk en ander bedrywighede mag toegee aan die ongebreidelde eise van performatiwiteit, operatiwiteit of managerialisme nie. Die toevoeging van waarde in Christene se lewe en in hulle werk behels meer as slegs prestasie in meetbare vorm. Dit hou in hoë mate verband met hulle verhouding met en gesindheid teenoor God, hulle Skepper en Onderhouer, hulle medemens (wat oorgeskiktes, werkgewers en medewerkers insluit). Dit hou ook verband met die gesindheid waarmee Christene die werk wat aan hulle toevertrou is, benader en uitvoer. Indien taakbewustheid, roepingsbesef, trou en getrouheid, inisiatief, ondernemingsgees, bereidheid tot dienslewering en tot die gee van rekenskap, die soek na die voordeel van die werkgewer (en die naaste in die algemeen), die besef en belewing van diepe vreugde, en dies meer, Christene se lewe, werk en algemene aktiwiteit kenmerk, sal waardetoevoeging vanselfsprekend ook plaasvind - en sal 'n mens dit in die meeste gevalle ook kan sien en meet, of minstens kwalitatief kan beskryf.

Indien waardetoevoeging en die meting daarvan die vernaamste doel word, soos deur die performatiwiteits- en operatiwiteitsbeginsels van die hoë moderniteit geverg word, dan word die proses in werklikheid omgekeer. Die positiewe eienskappe van die goeie werker, soos hierbo opgenoem, kan verdwyn - aangesien die mens en sy behoeftes uit die blikveld verdwyn. Sodra die waardigheid van die mens in die werkplek aangetas word, soos wat die norme van die hoë moderniteit neig om te doen, verdwyn ook die vreugde van die werker. Effektiwiteit en produktiwiteit sal saam daarmee daal.

Die gelykenis in Matteus 25:14-30 en Lukas 19:17-24 toon dat die vraagstuk van effektiwiteit en produktiwiteit juis van die kant van die mense in die werksverhouding benader moet word: die interpersoonlike verhouding tussen die eienaar / werkgewer en die slawe / werkers is deurslaggewend in 'n proses van effektiwiteits- en produktiwiteits- 
verbetering. 'n Vertrouensverhouding skyn deurslaggewend te wees vir 'n geslaagde uitset- of afrekeningsfase. Prestasie en die meetbaarheid daarvan is dus nie so belangrik soos die verhoudings en gesindhede tussen die betrokkenes nie. Prestasie en die bevredigende omvang daarvan kan wel 'n gevolg of uitvloeisel wees van 'n goeie verhouding en gesindheid tussen werkgewer en werknemer, eienaar en werker, bestuurder (leier) en volgelinge.

Die werker wat in die eerste plek vir God werk, en besef en beleef dat God hom/haar inroep om te deel in sy vreugde, sal effektief en produktief wees. Effektiwiteit en produktiwiteit mag nooit 'n doel op sigself wees wat naarstiglik nagejaag word nie; dit word die bonus, die toegevoegde waarde van 'n slaaf wat weet dat sy/haar eienaar met hom/haar tevrede is. So ' $n$ werker is vir elke werkgewer nie slegs 'n bate vanweë 'n hoë vlak van effektiwiteit en produktiwiteit nie, maar veral as 'n bron van aansteeklike lewens- en arbeidsvreugde.

\section{Bibliografie}

ASMAL, K. 1999. Asmal launches massive education mobilisation. Media Release. Pretoria : Ministry of Education.

BARCLAY, W. 1975. The Gospel of Matthew. Vol. 2. Edinburgh : St. Andrews.

BARTCHY, S.S. 1992. Slavery (New Testament). (In Freedman, D.N., ed. The Anchor Bible Dictionary. Vol Vl: 65(73). New York : Doubleday. p. .)

BLAKE, N., SMEYERS, P., SMITH, R. \& Standish, P. 1998. Thinking again (Education after Postmodernism). Westport : Bergin \& Harvey.

BOTHA, J. 1991. Reading Romans 13. Aspects of the ethics of interpretation in a controversial text. Stellenbosch : University of Stellenbosch. (D.Th.-Dissertation.)

CAMMERAAT, P. 1999. Leren en leven. Deel 3. Derde druk. Kampen : De Groot Goudriaan.

COETZEE, J.C., FLOOR, L., \& DE KLERK, B.J. 1980. Hermeneuse van die Skrif met die oog op hedendaagse kerklik-etiese vraagstukke. In die Skriflig, 54(1):12-26.

ELLIOTT, J.H. 1990. A home for the homeless. A sosial-scientific criticism of 1 Peter. Its situation and strategy. Philadelphia : Fortress Press.

FUNK, R.W. \& HOOVER, R.W. 1993. The Five Gospels. New York : MacMillan.

GARRETT, S.R. 1992. Sociology of early Christianity. (In Freedman, D.N. The Anchor Bible Dictionary. Vol. VI: 89-99. New York : Doubleday. p. 89-99.

GEERTSEMA, H.G. 1992. Het menselijk karakter van ons kennen. Amsterdam : Buijten \& Schipperheijn.

HARGREAVES, A. 1994. Changing teachers, changing times. Teachers' work and culture in the postmodern age. London : Cassell.

HENDRIKSEN, W. 1973. The gospel of Matthew. Edinburgh : Banner of Truth Trust.

HENRY, M. 1993. Commentary on the whole Bible. Peabody : Hendrickson.

HOPKINS, K. 1978. Conquerers and slaves. Sociological studies in Roman history. Volume 1. Cambridge : Cambridge University Press.

INTERPRETER'S BIBLE, THE. 1954. Vol. III. New York : Abingdon Press. 
JANSE VAN RENSBURG, Fika. 1992. Uitlanders en tydelike inwoners. 'n Sosiohistoriese studie van "vreemdelingskap" in 1 Petrus. Potchefstroom : PU vir $\mathrm{CHO}$.

JORDAAN, G.J.C. 1991. Skrifbeskouing: deurslaggewende faktor by Skrifverklaring. Potchefstroom : Departement Sentrale Publikasies, PU vir $\mathrm{CHO}$.

KOLE, I.A. 1992. New Age: Enkele aspecten. Kampen : Kok Voorhoeve.

LYOTARD, J-F. 1984. The postmodern condition: A report on knowledge. Manchester : University Press.

MACMULLEN, R. 1974. Roman social relations 50 B.C. to 284 A.D. New Haven : Yale University Press.

MALHERBE, A.J. 1983. (2 nd. enlarged ed.) Social aspects of early Christianity. Philadelphia : Fortress Press.

OZMON, H. \& CRAVER, S. 1995. Philosophical foundations of education. Englewood Cliffs : Merrill (Prentice Hall).

PESTALOZZI, H.A. 1979. Nach uns die Zukunft. München : Kösel.

RIDDERBOS, A. 1954. Het Evangelie naar Mattheüs. Deel. 2. Kampen : Kok.

ROBERTS, J.H. \& DU TOIT, A.B. 1977. Handleiding by die Nuwe Testament. Band 1. Inleiding tot die studie van die Nuwe Testament; Kanoniek van die Nuwe Testament. Pretoria : NG Kerkboekhandel.

SCHUURMAN, E. 1977. Reflections on the technological society. Jordan Station : Wedge.

SCHUURMAN, E. 1984. Information society: Impoverishment or enrichment of culture? Potchefstroom : Instituut vir Reformatoriese Studies.

SCHUURMAN, E. 1987. Perspectives on technology and culture. Potchefstroom : PU vir $\mathrm{CHO}$.

SCHUURMAN, E. 1995. The future: Our choice or God's gift? Wellington : Exile.

STAMBAUGH, J.E. \& BALCH, D.L. 1986. The New Testament in its social environment. Philadelphia : Westminister.

USHER, R. \& EDWARDS, R. 1994. Postmodernism and education: London : Routledge.

VAN BRUGGEN, J. 1990. Matteüs. Het Evangelie voor Israel. Kampen : Kok.

VAN DER WATT, J. \& JOUBERT, S. 1997. Die Boodskap. Vereeniging : CUM.

VAN RIESSEN, I.H. 1952. Roeping en probleem der techniek. Kampen : Kok.

VAN WYK, G.J. \& VAN RENSBURG, F.J. 1997. Oiketai (huisbediendes) in die eerste-eeuse Grieks-Romeinse samelewing. 'n Sosio-historiese konstruksie vir die interpretasie van 1 Petrus 2:18. In die Skriflig, 31(3):229-249.

VAN ZYL, H.C. 1999. Kommentaar op Matteus. (In Vosloo, W. \& Van Rensburg, Fika J. Die Bybellennium eenvolumekommentaar. Vereeniging : Christelike Uitgewersmaatskappy. p.1111-1187.)

ZAHN, T. 1910. Das Evangelium nach Matthaüs. Leipzich : Deichert.

\section{Kernbegrippe:}

effektiwiteit; Matt. 25:14-30

produktiwiteit; Matt. 25:14-30

roeping/roepingsvervulling; Matt. 25:14-30

\section{Key concepts:}

calling/vocation; Matt. 25:14-30

effectivity; Matt. 25:14-30

productivity; Matt. 25:14-30 